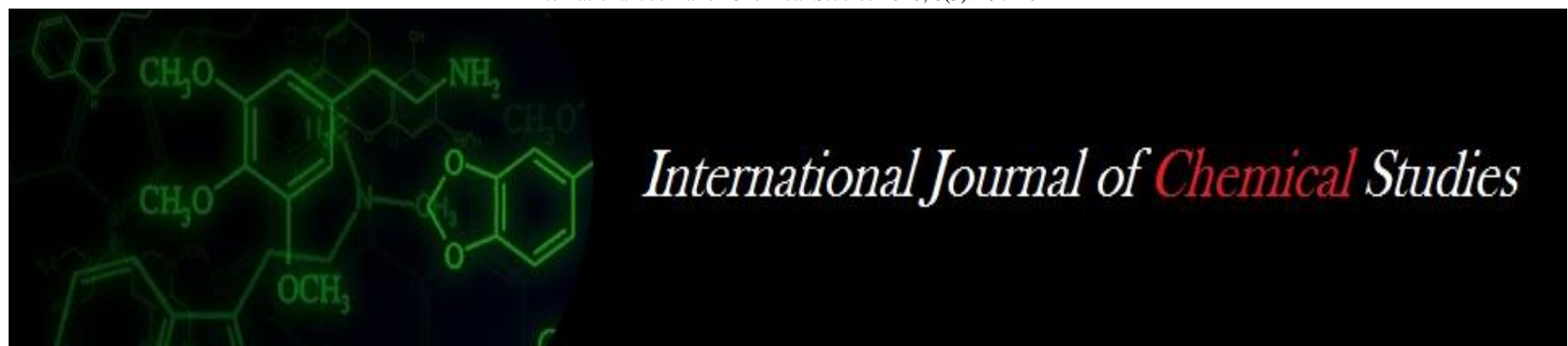

P-ISSN: 2349-8528

E-ISSN: 2321-4902

www.chemijournal.com

IJCS 2020; 8(5): 197-204

(C) 2020 IJCS

Received: 28-05-2020

Accepted: 18-07-2020

Sauvik Ganguly

Department of Agronomy,

University of Agricultural

Sciences, GKVK, Bengaluru,

Karnataka, India

BS Lalitha

Associate Professor, Department

of Agronomy, University of

Agricultural Sciences, GKVK,

Bengaluru, Karnataka, India

Gurunath Raddy

Ph.D. Research Scholar,

Department of Agronomy,

University of Agricultural

Sciences, GKVK, Bengaluru

Karnataka, India

RM Salman Khan

Ph.D. Research Scholar,

Department of Agronomy,

University of Agricultural

Sciences, GKVK, Bengaluru,

Karnataka, India
Corresponding Author: Gurunath Raddy

Ph.D. Research Scholar,

Department of Agronomy,

University of Agricultural

Sciences, GKVK, Bengaluru,

Karnataka, India

\section{Influence of combinations of different fodder crops on nutritional quality under hydroponic condition}

\author{
Sauvik Ganguly, BS Lalitha, Gurunath Raddy and RM Salman Khan
}

DOI: https://doi.org/10.22271/chemi.2020.v8.i5c.10299

\begin{abstract}
An experiment was conducted to study the influence of combinations of different fodder crops on nutritional quality under hydroponic condition at Agronomy field unit, Zonal Agricultural Research Station, Gandhi Krishi Vignana Kendra, University of Agricultural Sciences, Bangalore during the year 2018. The experiment was conducted with 13 treatment combinations involving maize, finger millet, little millet and cowpea at different proportions by using completely randomised design (CRD) and repeated three times. The results revealed that the crude protein and carbohydrate yield was highest in $100 \%$ Cowpea and $25 \%$ Cowpea $+75 \%$ Maize treatments compared to other treatments.
\end{abstract}

Keywords: Crude protein, fodder crops, carbohydrates, hydroponics

\section{Introduction}

In India, to meet out the nutritional and economic security for small and marginal farmers livestock plays a major role. The livestock population of India is 512.1 million including 190.9 million cattle $(37.27 \%)$, 108.1 million buffaloes $(21.10 \%), 65.1$ million sheep $(12.71 \%)$ and 135.2 million goats $(26.40 \%)$ (Anon., 2017) ${ }^{[2]}$. During last 61 years (1951-2012), the growth rate shows increasing trend in cattle $(28.17 \%)$, buffaloes $(142.7 \%)$, sheep $(83.01 \%)$ and goat $(197.7 \%)$ population and the overall growth rate in livestock is $80.89 \%$ (Anon., 2012) ${ }^{[3]}$. This increasing trend in the livestock population along with the intensive rearing system has resulted in the increase demands for feeds and fodder in the country. A good fodder supply is required for better livestock production and there is huge gap between demand and supply of green fodder and situation worsen during summer. The land available for cultivation of green fodder is very limited (only $5 \%$ of the gross cropped area); but by 2020 , India would require a total 526, 855 and 56 million tons of dry fodder, green fodder and concentrates, respectively (Dikshit and Brithal, 2010) ${ }^{[10]}$. So, there is need for an alternative green fodder production system to meet the demand of the growing livestock population.

The best alternate method for fodder cultivation is hydroponic fodder cultivation. For arid, dry climates or areas with short growing season hydroponic thus holds a better solution. Further, hydroponics require 1 to 2 litres of water to produce 1 kilogram of fodder when compared to conventional fodder production require 80-90 litres of water to grow 1 kilogram of green fodder. High water productivity is a major advantage of this technique and which saves about 95-97 per cent of water along with land required for fodder cultivation in conventional system (Al-Karaki and Al-Hasimi, 2012) ${ }^{[1]}$. Hydroponic fodder is a particularly nutritious feed, rich in crude protein and vitamins such as $\beta$ - carotene, trace elements (Marisco et al., 2009) ${ }^{[15]}$. The increase in crude protein (CP) content may be due to the loss in dry matter (DM), particularly carbohydrates, through respiration during germination and thus longer sprouting time was responsible for greater losses in DM and increase in protein content (Dung et al., 2010) ${ }^{[11]}$. Fodder quality between conventionally produced maize with its hydroponic production and observed higher protein, fat and soluble carbohydrates but less fibre total ash and acid soluble ash with hydroponic production (Naik et al., 2011) ${ }^{[21]}$. Chemical composition of conventional maize fodder vs. hydroponics maize was investigated under the experiment on technology for production and feeding of hydroponics green fodder. It was observed that there was increase in crude protein $(\mathrm{CP})$, extract ether (EE), crude fibre (CF) and total ash (TA) content and 
decrease in neutral detergent fibre (NFE) content during the growth of hydroponics maize fodder (Naik, 2012) ${ }^{[19]}$. Finger millet and little millet seeds are rich in starch and cell wall polysaccharides. This starch and polysaccharides constitute the maximum share of carbohydrate in millets (Lafindra and Shewry, 2014) ${ }^{[14]}$. The moisture content was highest in the roots $(15.68 \%)$ and lowest in the leaves $(6.81 \%)$ of the hydroponic maize fodder. The crude protein $(\mathrm{CP})$, crude fibre (CF) and total ash (TA) contents (\%) were highest in the leaves $(22.15,17.69$ and $3.84 \%)$ and lowest in the roots $(10.25,9.76$ and $1.59 \%)$. The ether extract content of the leaves $(2.90 \%)$ was similar with the roots $(3.01 \%)$ and plants $(2.29 \%)$ in hydroponic fodder (Naik et al., 2017) ${ }^{[22]}$.

\section{Material and methods}

The experiment was conducted at Agronomy field unit, ZARS, University of Agricultural Sciences, GKVK, Bengaluru. It comes under Eastern Dry Zone (Zone-V) of Karnataka situated at latitude of $13.08^{\circ} \mathrm{N}$ and longitude of $77.59^{\circ} \mathrm{E}$ with at an altitude of 930 meter above mean sea level. The hydroponic unit was designed with three stands, each of them having width of $75 \mathrm{~cm}$ and a height of $170 \mathrm{~cm}$ accommodating 5 trays. Each tray was made with vinyl fibre of dimensions $2.5 \mathrm{ft} \times 1.5 \mathrm{ft} \times 0.15 \mathrm{ft}$. Seeds of maize (South African Tall), finger millet (GPU 48), little millet (JK-8) and cowpea (KBC-2) were weighed and washed with freshwater and then soaked in fresh water for 24 hours in 1:2 proportion ( 1 part of seeds and 2 parts of water). After 24 hours the water was drained out and the seeds were then tied in a gunny bag and kept in dark. Water was sprinkled at 2-3 hours interval and incubated for another 24 hours for proper germination. After 24 hours, germinated seeds were transferred to trays and covered by wet gunny bag for 2-3 days for better growth and establishment. Later gunny bag was removed and trays were exposed to sunlight and watering was done as and when required. The samples were collected at $5^{\text {th }}, 10^{\text {th }}$ and $14^{\text {th }}$ days after sowing for proximate analysis.

The treatment details are $\mathrm{T}_{1}: 100 \%$ Finger millet, $\mathrm{T}_{2}: 75 \%$ Finger millet $+25 \%$ Cowpea, $\mathrm{T}_{3}: 50 \%$ Finger millet $+50 \%$ Cowpea, $\mathrm{T}_{4}: 25 \%$ Finger millet $+75 \%$ Cowpea, $\mathrm{T}_{5}: 100 \%$ Little millet, $\mathrm{T}_{6}: 75 \%$ Little millet $+25 \%$ Cowpea, $\mathrm{T}_{7}: 50 \%$ Little millet $+50 \%$ Cowpea, $\mathrm{T}_{8}: 25 \%$ Little millet $+75 \%$ Cowpea, $\mathrm{T}_{9}: 100 \%$ Maize, $\mathrm{T}_{10}: 75 \%$ Maize $+25 \%$ Cowpea, $\mathrm{T}_{11}: 50 \%$ Maize $+50 \%$ Cowpea, $\mathrm{T}_{12}: 25 \%$ Maize $+75 \%$ Cowpea, $\mathrm{T}_{13}: 100 \%$ Cowpea.

Plant sample was collected from each treatment were separately dried and powdered by using mixer grinder with stainless steel blade. The powdered samples were stored in air tight containers for further chemical analysis. The samples were used for $\mathrm{N}$, crude protein, crude fibre, carbohydrate, fat and ash content estimation.

The nitrogen content in plant was estimated by Micro Kjeldhal method (Jackson, 1967) ${ }^{[13]}$ and expressed in percentage on dry weight basis. Crude protein content of the plant was estimated from diacid digest by Micro kjeldhal method by multiplying the nitrogen content of the plant sample with the factor 6.25 as indicated by Crompton and Harris (1969) ${ }^{[8]}$ and later expressed in percentage.

Crude fibre content as percentage was estimated gravimetrically by successive digestion and washing of a weighted portion of the plant sample with dilute acid and alkali. The loss in weight after ignition was considered as crude fibre (AOAC, 2000) ${ }^{[5]}$ and later expressed in percentage.

$$
\text { Crude fibre }(\%)=\frac{\text { Loss in weight on ignition }\left[\left(\mathrm{W}_{2}-\mathrm{W}_{1}\right)\right.}{\text { Weight of the Sample }} \times 100
$$

Where,

$\mathrm{W}_{1}=$ Pre weighed dish

$\mathrm{W}_{2}=$ Oven dry weight of residue with dish

$\mathrm{W}_{3}=$ Weight of the ash with dish

The carbohydrate in plant sample was estimated by anthrone method. Plant sample of $100 \mathrm{mg}$ was weighted and kept into a boiling tube. Then hydrolyzation is done by keeping in a boiling water bath for three hours with $5.0 \mathrm{ml}$ of $2.5 \mathrm{~N} \mathrm{HCl}$. Then it is cooled to normal temperature and neutralized with sodium carbonate until the effervescence ceases. Then the volume made up to $100 \mathrm{ml}$ and centrifuged, the supernatant was collected and 0.2 to $1.0 \mathrm{ml}$ was taken for analysis. By using 0.2-1.0 ml of different working standards, different standards were prepared. $1.0 \mathrm{ml}$ of water served as a blank and the volume made up to $1.0 \mathrm{ml}$ with distilled water in all the tubes. Then $4.0 \mathrm{ml}$ of anthrone agent was added, heated for eight minutes in a boiling water bath, cooled rapidly and read the green to dark green colour at $630 \mathrm{~nm}$. A standard graph was prepared by taking concentration of glucose on $\mathrm{X}$ axis and spectrophotometer reading on $\mathrm{Y}$ axis. The concentration of carbohydrate in obtained from the graph (Hedge and Hofreiter, 1962) ${ }^{[12]}$ and later expressed in percentage.

$$
\text { Carbohydrate }(\%)=\frac{\text { Milligrams of glucose }}{\text { Volume of test sample }} \times 100
$$

Ash content was measured by ingestion of the dried material in a muffle furnace at $600{ }^{\circ} \mathrm{C}$ for 4 hours later expressed in percentage.

$$
\text { Ash }(\%)=\frac{\text { Weight of ash }}{\text { Weight of sample }} \times 100
$$

A dried, ground sample was extracted with diethyl ether using Goldfisch fat extraction apparatus, which dissolves fats, oils, pigments and other fat-soluble substances. The ether was then evaporated from the fat solution. The resulting residue was weighed and referred to as ether extract or crude fat.

$$
\text { Crude fat }(\%)=\frac{\left(\mathrm{W}_{2}-\mathrm{W}_{3}\right)}{\mathrm{W}_{1}} \times 100
$$

$\mathrm{W}_{1}=$ Initial sample weight in grams

$\mathrm{W}_{2}=$ Tare weight of beaker in grams

$\mathrm{W}_{3}=$ Weight of beaker and fat residue in grams

The crude protein yield was calculated by multiplying crude protein content with the dry matter yield and expressed in $\mathrm{kg}$ $\mathrm{m}^{-2}$.

$$
\begin{gathered}
\begin{array}{c}
\text { Crude protein yield } \\
\left(\mathrm{kg} \mathrm{m}^{-2}\right)=
\end{array} \\
\end{gathered} \begin{gathered}
\begin{array}{c}
\text { Crude protein content }(\%) \times \text { Dry } \\
\text { matter yield }\left(\mathrm{kg} \mathrm{m}^{-2}\right)
\end{array} \\
100
\end{gathered}
$$

The carbohydrate yield was calculated by multiplying crude protein content with the dry matter yield and expressed in $\mathrm{kg}$ $\mathrm{m}^{-2}$.

$$
\begin{gathered}
\text { Carbohydrate yield } \\
\left(\mathrm{kg} \mathrm{m}^{-2}\right)=
\end{gathered} \frac{\begin{array}{c}
\text { Carbohydrate content }(\%) \times \text { Dry } \\
\text { matter yield }\left(\mathrm{kg} \mathrm{m}^{-2}\right)
\end{array}}{100}
$$

The crude fibre yield was calculated by multiplying crude protein content with the dry matter yield and expressed in $\mathrm{kg}$ $\mathrm{m}^{-2}$. 
$\begin{gathered}\text { Crude fibre yield }(\mathrm{kg} \text { Crude fibre content }(\%) \times \text { Dry matter } \\ \text { yield }\left(\mathrm{kg} \mathrm{m}^{-2}\right)\end{gathered}$
$\left.\mathrm{m}^{-2}\right)=$$\frac{100}{100}$

\section{Results and Discussion}

The quality parameters of different fodder crops were significantly influenced by different treatment combinations.

\subsection{Nitrogen content}

At 5 DAS, significantly higher nitrogen content was found in $100 \%$ Cowpea $(3.12 \%)$ compared to all other treatments. The next best treatments with respect to nitrogen content are $25 \%$ Maize $+75 \%$ Cowpea $(2.54 \%)$ and $25 \%$ Little millet $+75 \%$ Cowpea $(2.40 \%)$. The significantly lower nitrogen content was recorded in $100 \%$ Finger millet $(0.52 \%)$. At 10 DAS, $100 \%$ Cowpea treatment recorded significantly higher nitrogen content $(3.54 \%)$ compared to all other treatments. The next best treatments with respect to nitrogen content are $25 \%$ Maize $+75 \%$ Cowpea $(2.98 \%)$ and $25 \%$ Little millet + $75 \%$ Cowpea $(2.83 \%)$. Significantly lower nitrogen content was found in $100 \%$ Finger millet $(0.97 \%)$. At 14 DAS (harvest), 100\% Cowpea was recorded significantly higher nitrogen content $(3.79 \%)$ compared to all other treatments. Significantly lower nitrogen content was found in $100 \%$ Finger millet (1.07\%).

$100 \%$ Cowpea has showed significantly higher nitrogen content at 5 DAS, 10 DAS and at 14 DAS (harvest). This might be due to the fact that cowpea is a legume crop and the seeds of cowpea having more protein content. As, nitrogen is the key component for construction of protein, seeds typically contain more amount of nitrogen than cereals (here, maize, finger millet and Little millet). Side by side, the sprouted seeds of cowpea may have more nitrogen reserve than unsprouted one (Anon., 2008) ${ }^{[4]}$. Treatments those had higher proportion of cowpea showed higher nitrogen content in comparison to $100 \%$ Finger millet and $100 \%$ Little millet. $100 \%$ Maize has shown more nitrogen content in comparison to $100 \%$ Finger millet and $100 \%$ Little millet. This was might be due to more nitrogen reserve in endosperm of sprouted maize seeds in comparison to finger millet and Little millet seeds. The data on of nitrogen content (\%) of different crops as influenced by treatment combinations is presented in table 3.1.

Table 3.1: Nitrogen content of hydroponically grown fodder crops as influenced by different treatment combinations

\begin{tabular}{|c|c|c|c|}
\hline \multirow{2}{*}{ Treatments } & \multicolumn{3}{|c|}{ Nitrogen content (\%) } \\
\cline { 2 - 3 } & 5 DAS & 10 DAS & 14 DAS \\
\hline $\mathrm{T}_{1}:$ 100\% Finger millet & 0.52 & 0.97 & 1.07 \\
\hline $\mathrm{T}_{2}:$ 75\% Finger millet + 25\% Cowpea & 1.11 & 1.55 & 1.70 \\
\hline $\mathrm{T}_{3}: 50 \%$ Finger millet + 50\% Cowpea & 1.94 & 2.41 & 2.56 \\
\hline $\mathrm{T}_{4}:$ 25\% Finger millet + 75\% Cowpea & 2.34 & 2.76 & 2.96 \\
\hline $\mathrm{T}_{5}:$ 100\% Little millet & 0.59 & 1.04 & 1.21 \\
\hline $\mathrm{T}_{6}:$ 75\% Little millet + 25\% Cowpea & 1.14 & 1.54 & 1.77 \\
\hline $\mathrm{T}_{7}: 50 \%$ Little millet + 50\% Cowpea & 2.09 & 2.52 & 2.70 \\
\hline $\mathrm{T}_{8}: 25 \%$ Little millet + 75\% Cowpea & 2.40 & 2.83 & 3.09 \\
\hline $\mathrm{T}_{9}: 100 \%$ Maize & 1.32 & 1.75 & 1.94 \\
\hline $\mathrm{T}_{10}:$ 75\% Maize + 25\% Cowpea & 1.65 & 2.08 & 2.27 \\
\hline $\mathrm{T}_{11}: 50 \%$ Maize + 50\% Cowpea & 2.13 & 2.51 & 2.75 \\
\hline $\mathrm{T}_{12}: 25 \%$ Maize + 75\% Cowpea & 2.54 & 2.98 & 3.12 \\
\hline $\mathrm{T}_{13}: 100 \%$ Cowpea & 3.12 & 3.54 & 3.79 \\
\hline S.E.m \pm & 0.014 & 0.016 & 0.044 \\
\hline C.D. @ 1\% & 0.041 & 0.047 & 0.13 \\
\hline
\end{tabular}

DAS: Days after sowing

\subsection{Crude protein content}

At 5 DAS, $100 \%$ Cowpea treatment recorded significantly higher crude protein content $(18.07 \%)$. The next best treatments with respect to crude protein content are $25 \%$ Maize $+75 \%$ Cowpea $(16.00 \%)$ and $25 \%$ Little millet $+75 \%$ Cowpea $(15.13 \%)$. Significantly lower crude was found in $100 \%$ Finger Millet (4.40\%). At 10 DAS, the crude protein content of $100 \%$ Cowpea was recorded significantly higher $(22.10 \%)$. The next best treatments with respect to crude protein content are $25 \%$ Maize $+75 \%$ Cowpea $(18.60 \%)$ and $25 \%$ Little millet $+75 \%$ Cowpea $(17.66 \%)$. Significantly lower crude protein content was found in $100 \%$ Finger millet $(6.06 \%)$. At 14 DAS (harvest), significantly higher crude protein content was found in $100 \%$ Cowpea $(22.64 \%)$. The next best treatments with respect to crude protein content are $25 \%$ Maize $+75 \%$ Cowpea $(19.52 \%)$ and $25 \%$ Little millet + $75 \%$ Cowpea (19.29\%). Significantly lower crude protein content was recorded in $100 \%$ Finger Millet (6.69\%).

The increase in crude protein content in $100 \%$ Cowpea treatment might be attributed to the loss in dry weight, particularly carbohydrates through respiration during germination and thus taken longer sprouting time which resulted in greater losses of dry weight and increasing trend in protein content. It might also be due to the nutrients change in sprouting seeds. The increase in crude protein may also be linked to nitrogen content. The nitrogen content of the sprouted fodder crops has showed an increasing trend with respect to time. This was might be associated with more amino acid formation. Hence, this increment in amino acid formation leads to more crude protein assimilation in plant system. The results are in confirmative with the findings of Morgan et al. (1992) ${ }^{[16]}$, Sneath and Mclntosh (2003) ${ }^{[24]}$. The absorption of nitrates facilitates the metabolism of nitrogenous compounds from carbohydrate reserves, intern that will increases the crude protein levels. These results corroborated with the findings of Morgan et al. (1992) ${ }^{[16]}$. The data on crude protein content (\%) of different crops as influenced by treatment combinations is presented in table 3.2 . 
Table 3.2: Crude protein content of hydroponically grown fodder crops as influenced by different treatment combinations

\begin{tabular}{|c|c|c|c|}
\hline \multirow{2}{*}{ Treatments } & \multicolumn{3}{|c|}{ Crude protein content (\%) } \\
\cline { 2 - 4 } & 5 DAS & 10 DAS & 14 DAS \\
\hline $\mathrm{T}_{1}:$ 100\% Finger millet & 4.40 & 6.06 & 6.69 \\
\hline $\mathrm{T}_{2}:$ 75\% Finger millet + 25\% Cowpea & 7.04 & 9.67 & 10.66 \\
\hline $\mathrm{T}_{3}: 50 \%$ Finger millet + 50\% Cowpea & 12.27 & 15.04 & 16.00 \\
\hline $\mathrm{T}_{4}:$ 25\% Finger millet + 75\% Cowpea & 14.75 & 17.23 & 18.88 \\
\hline $\mathrm{T}_{5}:$ 100\% Little millet & 4.83 & 6.93 & 7.56 \\
\hline $\mathrm{T}_{6}:$ 75\% Little millet + 25\% Cowpea & 7.27 & 9.62 & 11.11 \\
\hline $\mathrm{T}_{7}: 50 \%$ Little millet + 50\% Cowpea & 13.21 & 15.75 & 16.90 \\
\hline $\mathrm{T}_{8}: 25 \%$ Little millet + 75\% Cowpea & 15.13 & 17.66 & 19.29 \\
\hline $\mathrm{T}_{9}: 100 \%$ Maize & 8.39 & 10.94 & 12.11 \\
\hline $\mathrm{T}_{10}: 75 \%$ Maize + 25\% Cowpea & 10.42 & 12.98 & 14.21 \\
\hline $\mathrm{T}_{11}: 50 \%$ Maize + 50\% Cowpea & 13.47 & 15.69 & 17.17 \\
\hline $\mathrm{T}_{12}: 25 \%$ Maize + 75\% Cowpea & 16.00 & 18.60 & 19.52 \\
\hline $\mathrm{T}_{13}:$ 100\% Cowpea & 18.07 & 22.10 & 22.64 \\
\hline S.E.m \pm & 0.091 & 0.101 & 0.423 \\
\hline C.D. @ 1\% & 0.267 & 0.294 & 1.237 \\
\hline
\end{tabular}

DAS: Days after sowing

\subsection{Crude protein yield}

At 5 DAS, significantly higher crude protein yield was found in $100 \%$ Cowpea $\left(0.26 \mathrm{~kg} / \mathrm{m}^{2}\right)$. The next best treatment with respect to crude protein yield are $25 \%$ Maize $+75 \%$ Cowpea $\left(0.23 \mathrm{~kg} / \mathrm{m}^{2}\right)$. Significantly lower crude protein yield was recorded in $100 \%$ Finger Millet $\left(0.03 \mathrm{~kg} / \mathrm{m}^{2}\right)$ and $100 \%$ Little millet $\left(0.03 \mathrm{~kg} / \mathrm{m}^{2}\right)$. At $10 \mathrm{DAS}, 100 \%$ Cowpea treatment recorded significantly higher crude protein yield $\left(0.38 \mathrm{~kg} / \mathrm{m}^{2}\right)$. The next best treatments with respect to crude protein yield are $25 \%$ Maize $+75 \%$ Cowpea $\left(0.33 \mathrm{~kg} / \mathrm{m}^{2}\right)$. Significantly lower crude protein yield was recorded at $100 \%$ Finger Millet $\left(0.06 \mathrm{~kg} / \mathrm{m}^{2}\right)$ and $100 \%$ Little millet $\left(0.06 \mathrm{~kg} / \mathrm{m}^{2}\right)$. At 14 DAS (harvest), the crude protein yield of $100 \%$ Cowpea was recorded significantly higher $\left(0.50 \mathrm{~kg} / \mathrm{m}^{2}\right)$. The next best treatment with respect to crude protein yield is $25 \%$ Maize + $75 \%$ Cowpea $\left(0.45 \mathrm{~kg} / \mathrm{m}^{2}\right)$. Significantly lower crude protein yield was observed in $100 \%$ Finger millet $\left(0.08 \mathrm{~kg} / \mathrm{m}^{2}\right)$.

The high crude protein yield in $100 \%$ Cowpea was mainly attributed to higher crude protein content and higher dry matter yield. As the $100 \%$ Cowpea treatment was having more crude protein content as well as increasing trend of dry matter yield, it resulted in high crude protein yield compare to other treatments These results corroborated with the findings of Morgan et al. (1992) ${ }^{[16]}$. The data on crude protein yield $\left(\mathrm{kg} / \mathrm{m}^{2}\right)$ of different crops as influenced by treatment combinations is presented in fig. 3.1.

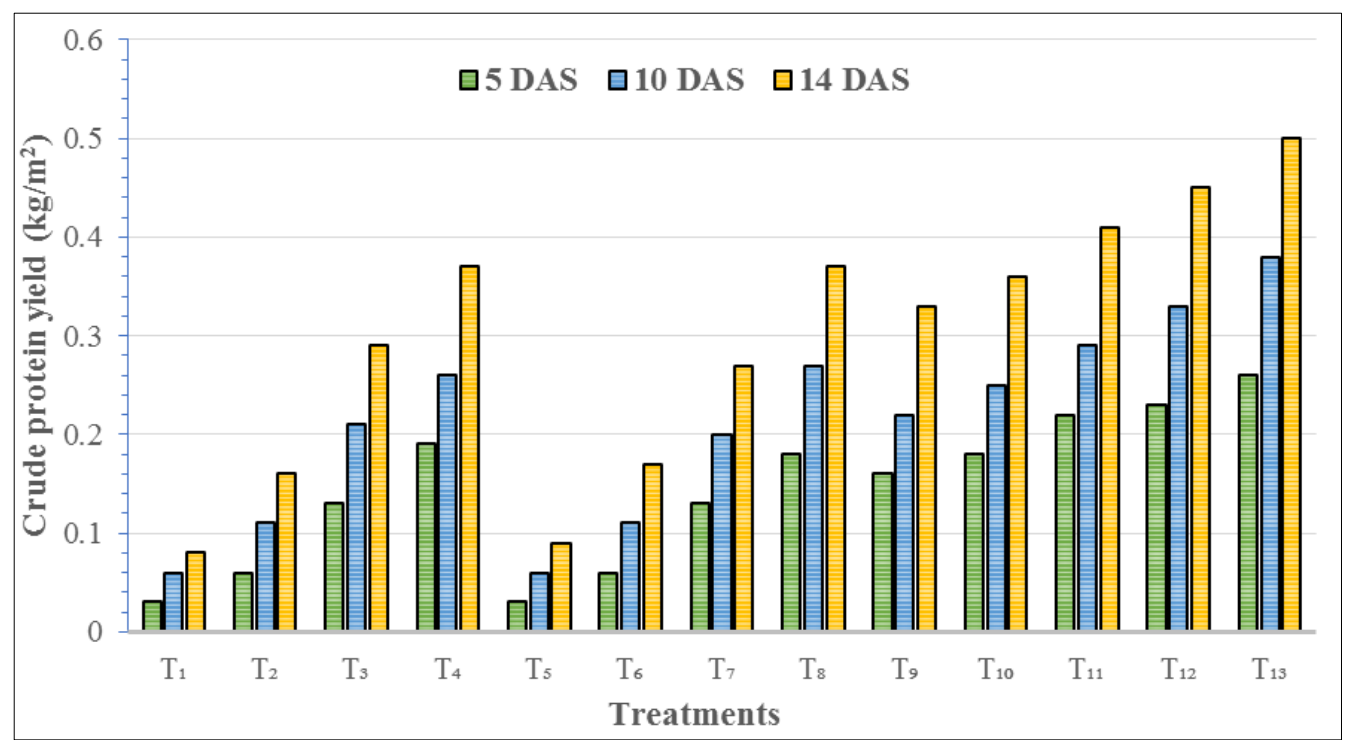

Fig 3.1: Crude protein yield of hydroponically grown fodder crops as influenced by different treatment combinations

\subsection{Carbohydrate content}

At 5 DAS, 100\% Little millet treatment recorded significantly higher carbohydrate content $(34.55 \%)$. The next best treatments with respect to carbohydrate content are $100 \%$ Finger millet $(33.37 \%)$ and $75 \%$ Little millet $+25 \%$ Cowpea $(33.36 \%)$. Significantly lower carbohydrate content was recorded in $100 \%$ Cowpea $(20.84 \%)$. At 10 DAS, the carbohydrate content of $100 \%$ Little millet was recorded significantly higher $(43.78 \%)$. The next best treatments with respect to carbohydrate content are $100 \%$ Finger millet $(41.05 \%)$ and $75 \%$ Little millet $+25 \%$ Cowpea $(39.97 \%)$.
Significantly lower carbohydrate content was found in $100 \%$ Cowpea (28.70\%). At 14 DAS (harvest), significantly higher carbohydrate content was found in $100 \%$ Little millet $(49.26 \%)$. The next best treatments with respect to carbohydrate content are $75 \%$ Little millet $+25 \%$ Cowpea $(47.96 \%)$ and $100 \%$ Finger millet (45.90\%). Significantly lower carbohydrate content was recorded in $100 \%$ Cowpea $(35.66 \%)$.

Treatment contain 100\% Little millet and 100\% Finger millet and all millet associated treatments has shown highest carbohydrate content. This was because of little and finger 
millet seeds are rich in starch and cell wall polysaccharides. This starch and polysaccharides constitute the maximum share of carbohydrate in millets. These results corroborated with the findings of Lafiandra and Shewry (2014) ${ }^{[14]}$. The data on carbohydrate content (\%) of different crops as influenced by treatment combinations is presented in table 3.3.

Table 3.3: Carbohydrate content of hydroponically grown fodder crops as influenced by different treatment combinations

\begin{tabular}{|c|c|c|c|}
\hline \multirow{2}{*}{ Treatments } & \multicolumn{3}{|c|}{ Carbohydrate content (\%) } \\
\cline { 2 - 4 } & 5 DAS & 10 DAS & 14 DAS \\
\hline $\mathrm{T}_{1}:$ 100\% Finger millet & 31.37 & 41.05 & 45.90 \\
\hline $\mathrm{T}_{2}:$ 75\% Finger millet + 25\% Cowpea & 28.73 & 37.34 & 42.16 \\
\hline $\mathrm{T}_{3}: 50 \%$ Finger millet + 50\% Cowpea & 23.52 & 32.30 & 38.96 \\
\hline $\mathrm{T}_{4}: 25 \%$ Finger millet + 75\% Cowpea & 22.37 & 31.73 & 37.98 \\
\hline $\mathrm{T}_{5}: 100 \%$ Little millet & 34.55 & 43.78 & 49.26 \\
\hline $\mathrm{T}_{6}: 75 \%$ Little millet + 25\% Cowpea & 31.36 & 39.97 & 47.96 \\
\hline $\mathrm{T}_{7}: 50 \%$ Little millet + 50\% Cowpea & 28.82 & 36.99 & 42.60 \\
\hline $\mathrm{T}_{8}: 25 \%$ Little millet + 75\% Cowpea & 24.40 & 36.49 & 38.72 \\
\hline $\mathrm{T}_{9}: 100 \%$ Maize & 22.34 & 31.69 & 37.43 \\
\hline $\mathrm{T}_{10}:$ 75\% Maize + 25\% Cowpea & 24.12 & 33.23 & 38.06 \\
\hline $\mathrm{T}_{11}: 50 \%$ Maize + 50\% Cowpea & 22.34 & 31.73 & 36.92 \\
\hline $\mathrm{T}_{12}: 25 \%$ Maize + 75\% Cowpea & 22.17 & 30.04 & 36.40 \\
\hline $\mathrm{T}_{13}:$ 100\% Cowpea & 20.84 & 28.70 & 35.66 \\
\hline S.E.m \pm & 0.167 & 0.363 & 0.215 \\
\hline C.D. @ 1\% & 0.489 & 1.062 & 0.628 \\
\hline
\end{tabular}

DAS: Days after sowing

\subsection{Carbohydrate yield}

At 5 DAS, the carbohydrate yield of $75 \%$ Maize $+25 \%$ Cowpea was recorded significantly higher $\left(0.43 \mathrm{~kg} / \mathrm{m}^{2}\right)$. Significantly lower carbohydrate yield was found in $100 \%$ Finger millet $\left(0.19 \mathrm{~kg} / \mathrm{m}^{2}\right)$. The carbohydrate yield next to $75 \%$ Maize $+25 \%$ Cowpea were found in $100 \%$ Maize $(0.41$ $\left.\mathrm{kg} / \mathrm{m}^{2}\right)$ and $50 \%$ Maize $+50 \%$ Cowpea $\left(0.37 \mathrm{~kg} / \mathrm{m}^{2}\right)$. At 10 DAS, significantly higher carbohydrate yield was found in $75 \%$ Maize $+25 \%$ Cowpea $\left(0.63 \mathrm{~kg} / \mathrm{m}^{2}\right)$. The carbohydrate yield next to $75 \%$ Maize $+25 \%$ Cowpea was found in $100 \%$ Maize $\left(0.62 \mathrm{~kg} / \mathrm{m}^{2}\right)$. Significantly lower carbohydrate yield was recorded in $100 \%$ Little millet $\left(0.29 \mathrm{~kg} / \mathrm{m}^{2}\right)$. At 14 DAS (harvest), $100 \%$ Maize treatment recorded significantly higher carbohydrate yield $\left(1.00 \mathrm{~kg} / \mathrm{m}^{2}\right)$. Significantly lower carbohydrate yield was found in $100 \%$ Finger millet $(0.58$ $\mathrm{kg} / \mathrm{m}^{2}$ ). The next best treatment with respect to carbohydrate yield is $75 \%$ Maize $+25 \%$ Cowpea $\left(0.96 \mathrm{~kg} / \mathrm{m}^{2}\right)$. This sort of variation was mainly attributed to higher carbohydrate content and higher dry matter yield. Though $100 \%$ Little millet was having more carbohydrate content but due to less dry matter yield, carbohydrate yield has given lower value to the treatment. On the other hand, though carbohydrate content in $100 \%$ Maize and maize associated treatments was less than $100 \%$ Little millet but due to higher dry matter yield in those treatments, they have given higher carbohydrate yield. These results corroborated with the findings of Ravindran, G. (1991) [23] and Naik (2012) ${ }^{[19]}$. The data on carbohydrate yield $\left(\mathrm{kg} / \mathrm{m}^{2}\right)$ of different crops as influenced by treatment combinations is presented in fig. 3.2.

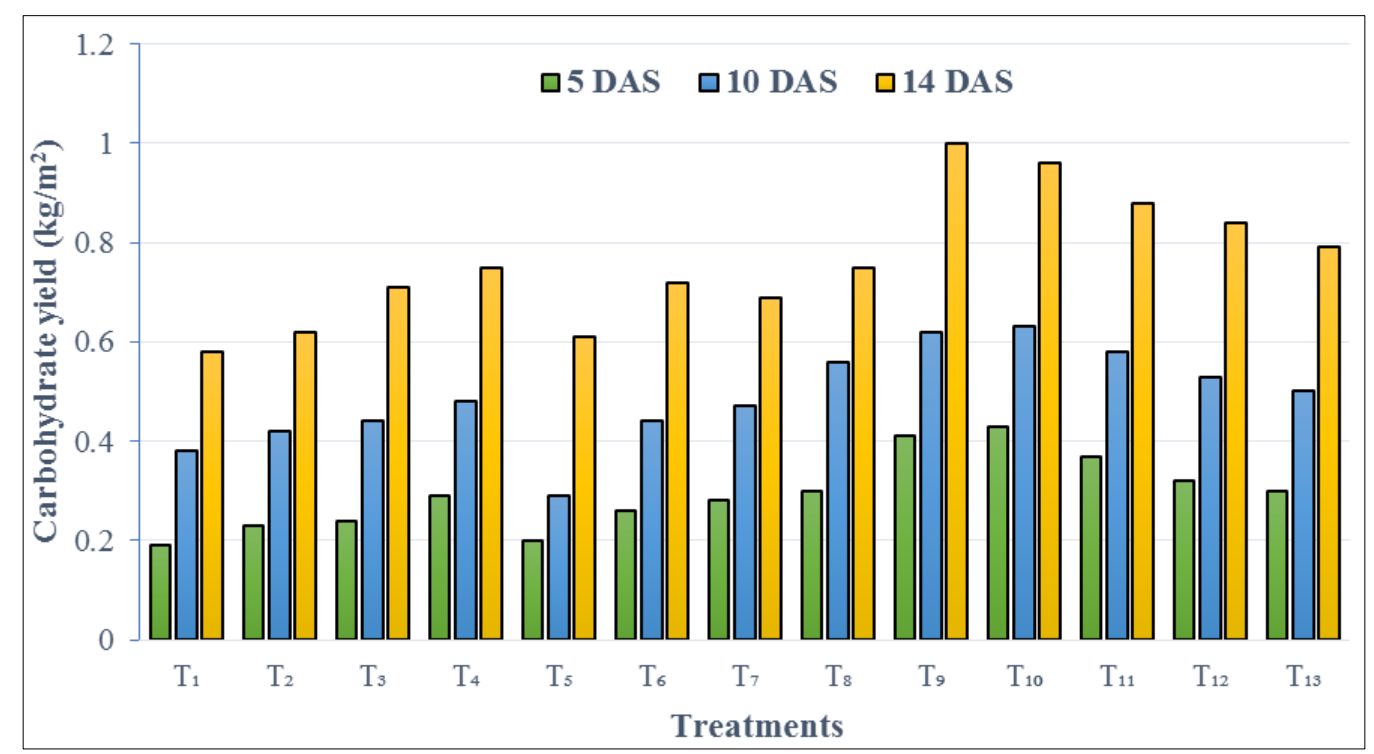

Fig 3.2: Carbohydrate yield of hydroponically grown fodder crops as influenced by different treatment combinations

\subsection{Crude fibre content}

At 5 DAS, the crude fibre content of $100 \%$ Maize was recorded significantly higher $(8.83 \%)$. Significantly lower crude fibre content was found in $100 \%$ Little millet $(5.40 \%)$.
The crude fibre content next to $100 \%$ Maize were found in $75 \%$ Maize $+25 \%$ Cowpea $(8.21 \%)$ and $25 \%$ Maize $+75 \%$ Cowpea $(7.77 \%)$. At 10 DAS, $100 \%$ Maize treatment recorded significantly higher crude fibre content (10.13\%). 
The next best treatments with respect to crude fibre content are $75 \%$ Maize $+25 \%$ Cowpea $(9.69 \%)$ and $50 \%$ Maize + $50 \%$ Cowpea (9.34\%). Significantly lower crude fibre content was found in $100 \%$ Little millet $(7.02 \%)$. At 14 DAS (harvest), significantly higher crude fibre content was found in $100 \%$ Maize $(15.46 \%)$. The next best treatments with respect to crude fibre content are $75 \%$ Maize $+25 \%$ Cowpea $(14.19 \%)$ and $50 \%$ Maize $+50 \%$ Cowpea (13.50\%). Significantly lower crude fibre content was recorded in $100 \%$ Little millet (10.34\%).
Increase in crude fibre content in $100 \%$ Cowpea was observed as the age advances. This was might be due to the effect of successive cell wall concentration with the advancement of the age and synthesis of structural carbohydrates such as cellulose and hemicelluloses. The results are in conformation with the findings of Chung et al. (1989) ${ }^{[7]}$ and Cuddeford (1989) ${ }^{[7]}$. The data on crude fibre content $(\%)$ of different crops as influenced by treatment combinations is presented in table 3.4.

Table 3.4: Crude fibre content of hydroponically grown fodder crops as influenced by different treatment combinations

\begin{tabular}{|c|c|c|c|}
\hline \multirow{2}{*}{ Treatments } & \multicolumn{3}{|c|}{ Crude fibre content (\%) } \\
\cline { 2 - 4 } & 5 DAS & 10 DAS & 14 DAS \\
\hline $\mathrm{T}_{1}:$ 100\% Finger millet & 5.63 & 7.05 & 10.56 \\
\hline $\mathrm{T}_{2}:$ 75\% Finger millet + 25\% Cowpea & 5.83 & 7.44 & 10.79 \\
\hline $\mathrm{T}_{3}: 50 \%$ Finger millet + 50\% Cowpea & 6.43 & 7.88 & 11.30 \\
\hline $\mathrm{T}_{4}:$ 25\% Finger millet + 75\% Cowpea & 6.26 & 8.30 & 11.41 \\
\hline $\mathrm{T}_{5}:$ 100\% Little millet & 5.40 & 7.02 & 10.34 \\
\hline $\mathrm{T}_{6}:$ 75\% Little millet + 25\% Cowpea & 5.68 & 7.53 & 10.57 \\
\hline $\mathrm{T}_{7}: 50 \%$ Little millet + 50\% Cowpea & 6.01 & 7.84 & 10.91 \\
\hline $\mathrm{T}_{8}:$ 25\% Little millet + 75\% Cowpea & 6.14 & 8.56 & 11.52 \\
\hline $\mathrm{T}_{9}: 100 \%$ Maize & 8.83 & 10.13 & 15.46 \\
\hline $\mathrm{T}_{10}:$ 75\% Maize + 25\% Cowpea & 8.21 & 9.69 & 14.19 \\
\hline $\mathrm{T}_{11}: 50 \%$ Maize + 50\% Cowpea & 7.74 & 9.34 & 13.50 \\
\hline $\mathrm{T}_{12}: 25 \%$ Maize + 75\% Cowpea & 7.77 & 9.04 & 12.90 \\
\hline $\mathrm{T}_{13}: 100 \%$ Cowpea & 6.32 & 8.89 & 11.78 \\
\hline S.E.m \pm & 0.021 & 0.028 & 0.03 \\
\hline C.D. @ 1\% & 0.062 & 0.081 & 0.088 \\
\hline
\end{tabular}

DAS: Days after sowing

\subsection{Crude fibre yield}

At 5 DAS, significantly higher crude fibre yield was found in $100 \%$ Maize $\left(0.16 \mathrm{~kg} / \mathrm{m}^{2}\right)$. The next best treatments with respect to crude fibre yield are $75 \%$ Maize $+25 \%$ Cowpea $\left(0.14 \mathrm{~kg} / \mathrm{m}^{2}\right)$ and $50 \%$ Maize $+50 \%$ Cowpea $\left(0.13 \mathrm{~kg} / \mathrm{m}^{2}\right)$. Significantly lower crude fibre yield was recorded $100 \%$ Little millet $\left(0.03 \mathrm{~kg} / \mathrm{m}^{2}\right)$. At $10 \mathrm{DAS}$, the crude fibre yield of $100 \%$ Maize was recorded significantly higher $\left(0.20 \mathrm{~kg} / \mathrm{m}^{2}\right)$. Significantly lower crude fibre yield was recorded in $100 \%$ Little millet $\left(0.06 \mathrm{~kg} / \mathrm{m}^{2}\right)$. The crude fibre yield next to $100 \%$ Maize were found in $75 \%$ Maize $+25 \%$ Cowpea $(0.19$ $\left.\mathrm{kg} / \mathrm{m}^{2}\right)$ and $50 \%$ Maize $+50 \%$ Cowpea $\left(0.17 \mathrm{~kg} / \mathrm{m}^{2}\right)$. At 14 DAS (harvest), $100 \%$ Maize treatment recorded significantly higher crude fibre yield $\left(0.41 \mathrm{~kg} / \mathrm{m}^{2}\right)$. The next best treatment with respect to crude fibre yield is $75 \%$ Maize $+25 \%$ Cowpea $\left(0.35 \mathrm{~kg} / \mathrm{m}^{2}\right)$. Significantly lower crude fibre yields were recorded at $100 \%$ Little millet $\left(0.13 \mathrm{~kg} / \mathrm{m}^{2}\right)$ and $100 \%$ Finger Millet $\left(0.13 \mathrm{~kg} / \mathrm{m}^{2}\right)$.

This was mainly attributed to higher crude fibre content and higher dry matter yield. As the $100 \%$ Maize treatment was having more crude fibre content as well as increasing trend of dry matter yield over time, it finally resulted in high crude fibre yield compare to other treatments These results corroborated with the findings of Chung et al. (1989) ${ }^{[7]}$ and Cuddeford (1989) ${ }^{[7]}$. The data on crude fibre yield $\left(\mathrm{kg} / \mathrm{m}^{2}\right)$ of different crops as influenced by treatment combinations is presented in fig. 3.3.

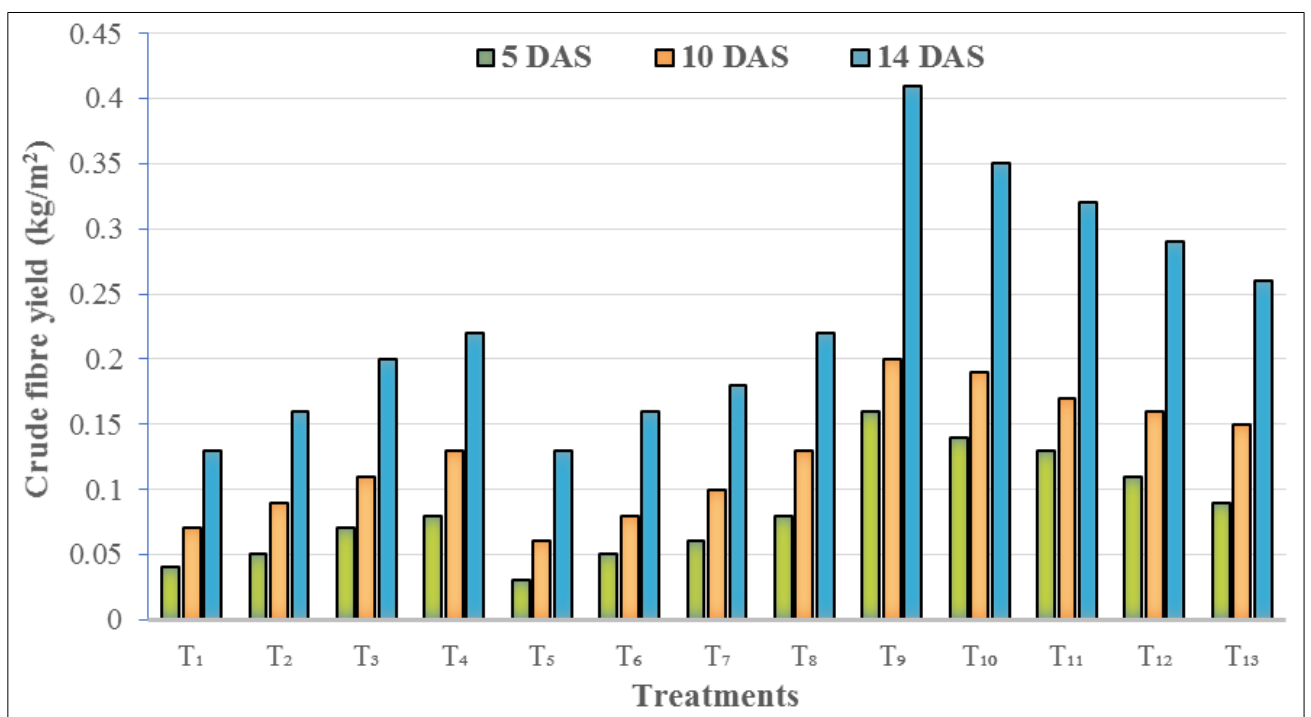

Fig 3.3: Crude fibre yield of hydroponically grown fodder crops as influenced by different treatment combinations 


\subsection{Fat content}

At 5 DAS, the fat content of $100 \%$ Cowpea was recorded significantly higher $(3.52 \%)$. Significantly lower fat content was recorded in $100 \%$ Finger Millet $(0.93 \%)$. The fat content next to $100 \%$ Cowpea were found in $50 \%$ Little millet $+50 \%$ Cowpea (3.49\%) and 100\% Little millet (3.39\%). At 10 DAS, significantly higher fat content was found in $100 \%$ Cowpea $(4.07 \%)$. The fat content next to $100 \%$ Cowpea was recorded in $50 \%$ Little millet $+50 \%$ Cowpea $(4.05 \%)$. Significantly lower fat content was found in $100 \%$ Finger millet $(1.56 \%)$. At 14 DAS (harvest), 100\% Cowpea treatment recorded significantly higher fat content $(4.40 \%)$. The next best treatments with respect to fat content are 50\% Little millet + $50 \%$ Cowpea $(4.31 \%)$ and $100 \%$ Little millet (4.21\%). Significantly lower fat content was found in $100 \%$ Finger Millet $(1.82 \%)$.

The increase in crude fat in $100 \%$ Cowpea treatment might be due to higher chlorophyll content in growing plant with advancement of age. These results are in line with the findings of Mayer and Poljakoff-Mayber (1974) ${ }^{[25]}$. The data on crude fibre content (\%) of different crops as influenced by treatment combinations is presented in table 3.5.

Table 3.5: Fat content of hydroponically grown fodder crops as influenced by different treatment combinations

\begin{tabular}{|c|c|c|c|}
\hline \multirow{2}{*}{ Treatments } & \multicolumn{3}{|c|}{ Fat content (\%) } \\
\cline { 2 - 4 } & 5 DAS & $\mathbf{1 0}$ DAS & $\mathbf{1 4}$ DAS \\
\hline $\mathrm{T}_{1}:$ 100\% Finger millet & 0.93 & 1.56 & 1.82 \\
\hline $\mathrm{T}_{2}:$ 75\% Finger millet + 25\% Cowpea & 1.48 & 2.06 & 2.33 \\
\hline $\mathrm{T}_{3}: 50 \%$ Finger millet + 50\% Cowpea & 2.21 & 2.67 & 3.06 \\
\hline $\mathrm{T}_{4}:$ 25\% Finger millet + 75\% Cowpea & 2.62 & 3.16 & 3.57 \\
\hline $\mathrm{T}_{5}:$ 100\% Little millet & 3.39 & 3.94 & 4.21 \\
\hline $\mathrm{T}_{6}:$ 75\% Little millet + 25\% Cowpea & 3.26 & 3.82 & 4.07 \\
\hline $\mathrm{T}_{7}: 50 \%$ Little millet + 50\% Cowpea & 3.49 & 4.05 & 4.31 \\
\hline $\mathrm{T}_{8}: 25 \%$ Little millet + 75\% Cowpea & 2.93 & 3.42 & 3.87 \\
\hline $\mathrm{T}_{9}: 100 \%$ Maize & 2.87 & 3.36 & 3.87 \\
\hline $\mathrm{T}_{10}:$ 75\% Maize + 25\% Cowpea & 3.08 & 3.55 & 3.95 \\
\hline $\mathrm{T}_{11}: 50 \%$ Maize + 50\% Cowpea & 3.32 & 3.82 & 4.17 \\
\hline $\mathrm{T}_{12}: 25 \%$ Maize + 75\% Cowpea & 3.27 & 3.84 & 4.11 \\
\hline $\mathrm{T}_{13}:$ 100\% Cowpea & 3.52 & 4.07 & 4.40 \\
\hline S.E.m \pm & 0.018 & 0.014 & 0.03 \\
\hline C.D. @ 1\% & 0.051 & 0.04 & 0.089 \\
\hline
\end{tabular}

DAS: Days after sowing

\subsection{Ash content}

At 5 DAS, significantly higher ash content was found in $100 \%$ Maize $(2.28 \%)$. The next best treatments with respect to ash content are $75 \%$ Maize $+25 \%$ Cowpea $(1.95 \%)$ and $50 \%$ Maize $+50 \%$ Cowpea $(1.89 \%)$. Significantly lower ash content was recorded in $75 \%$ Little millet $+25 \%$ Cowpea $(1.24 \%)$. At 10 DAS, the ash content of $100 \%$ Maize was recorded significantly higher $(2.82 \%)$. Significantly lower ash content was recorded in $100 \%$ Little millet $(2.11 \%)$. The ash content next to $100 \%$ Maize were found in $75 \%$ Maize $+25 \%$ Cowpea $(2.69 \%)$ and $50 \%$ Maize $+50 \%$ Cowpea $(2.56 \%)$. At 14 DAS (harvest), $100 \%$ Maize treatment recorded significantly higher ash content (4.01\%). The next best treatments with respect to ash content are $75 \%$ Maize $+25 \%$
Cowpea $(3.76 \%)$ and $50 \%$ Maize $+50 \%$ Cowpea $(3.59 \%)$. Significantly lower ash content was recorded in $100 \%$ Little millet $(3.08 \%)$.

There was an increasing trend in the ash content with the advancement of the period. This was due to the increased mineral uptake by the plants and the organic matter present in the sprouted seeds was utilized by growing seedlings as a source of energy for various metabolic activities which might have resulted in higher ash content. The results are in conformation with the results of Chavan and Kadam (1989) [6]. The data on ash content (\%) of different crops as influenced by treatment combinations is presented in table 3.6.

Table 3.6: Ash content of hydroponically grown fodder crops as influenced by different treatment combinations

\begin{tabular}{|c|c|c|c|}
\hline \multirow{2}{*}{ Treatments } & \multicolumn{3}{|c|}{ Ash Content (\%) } \\
\cline { 2 - 4 } & 5 DAS & 10 DAS & 14 DAS \\
\hline $\mathrm{T}_{1}:$ 100\% Finger millet & 1.37 & 2.24 & 3.14 \\
\hline $\mathrm{T}_{2}:$ 75\% Finger millet + 25\% Cowpea & 1.31 & 2.18 & 3.19 \\
\hline $\mathrm{T}_{3}: 50 \%$ Finger millet + 50\% Cowpea & 1.42 & 2.36 & 3.26 \\
\hline $\mathrm{T}_{4}:$ 25\% Finger millet + 75\% Cowpea & 1.50 & 2.37 & 3.39 \\
\hline $\mathrm{T}_{5}:$ 100\% Little millet & 1.28 & 2.11 & 3.08 \\
\hline $\mathrm{T}_{6}:$ 75\% Little millet + 25\% Cowpea & 1.24 & 2.18 & 3.12 \\
\hline $\mathrm{T}_{7}: 50 \%$ Little millet + 50\% Cowpea & 1.39 & 2.21 & 3.19 \\
\hline $\mathrm{T}_{8}: 25 \%$ Little millet + 75\% Cowpea & 1.50 & 2.31 & 3.33 \\
\hline $\mathrm{T}_{9}: 100 \%$ Maize & 2.28 & 3.21 & 4.01 \\
\hline $\mathrm{T}_{10}:$ 75\% Maize + 25\% Cowpea & 1.95 & 2.69 & 3.76 \\
\hline $\mathrm{T}_{11}: 50 \%$ Maize + 50\% Cowpea & 1.89 & 2.56 & 3.59 \\
\hline $\mathrm{T}_{12}: 25 \%$ Maize + 75\% Cowpea & 1.67 & 2.44 & 3.41 \\
\hline $\mathrm{T}_{13}:$ 100\% Cowpea & 1.52 & 2.39 & 3.31 \\
\hline S.E.m \pm & 0.016 & 0.017 & 0.014 \\
\hline C.D. @ 1\% & 0.047 & 0.05 & 0.04 \\
\hline
\end{tabular}

DAS: Days after sowing 


\section{Conclusion}

Hydroponic fodder production becoming more and more common in countries where the outdoors is more vulnerable to climate change. It can be practiced in indoors and is more effective this way, as we can control the climate, and ensures a high yield. For arid, dry climates or areas with short growing season hydroponic thus holds a better solution. To get more crude protein and carbohydrate yield, 100\% Cowpea and $25 \%$ Cowpea $+75 \%$ Maize treatments are the best under hydroponics.

\section{References}

1. Al-Karaki GN, Al-Hasimi M. Green fodder production and water use efficiency of some forage crops under hydroponic condition. Int School of Res. Network. 2012; 40:2-20.

2. Anonymous. Basic animal husbandry statistics. Department of Animal Husbandry, Dairying and Fisheries, Ministry of Agriculture, Govt. of India, Krishna Bhawan, New Delhi, 2017, 1-152.

3. Anonymous. Hydroponics green fodder feeding technology in Goa, Indian Council of Agricultural Research (Ministry of Agriculture and Farmers Welfare), 2012. www.icar.org.in.

4. Anonymous. Nutritional composition of cowpea seeds, 2008. www.nutrition-and-you.com.

5. AOAC. Official methods of analysis. $17^{\text {th }}$ Ed: Association of official analytical chemists, Washington, DC, USA, 2000

6. Chavan J, Kadam SS. Nutritional improvement of cereals by sprouting. Critical Rev. Food Sci. and Nutr. 1989; 28(5):401-437.

7. Chung TY, Nwokolo EN, Sim JS. Compositional and digestibility changes in sprouted barley and canola grains. J Plant Foods Human Nutr. 1989; 39(3):267-278.

8. Crompton HW, Harris LE. Applied Animal Nutrition (2). W. H. Freeman and Co., San Francisco, 1969.

9. Cuddeford D. Hydroponic grass In Practice. 1989; 11(5):211-214

10. Dikshit AK, Birthal PS. India's livestock feed demand: estimates and projections. Agric Economics Res. Rev. 2010; 3:15-28.

11. Dung DD, Gowdin IR, Nolan JV. Nutrient content and in sacco degradability of barley grain and sprouted barley. $\mathrm{J}$ Ani. Veter. Adv. 2010; 9(18):2485-2492.

12. Hedge JE, Hofreiter BT. In: Carbohydrate Chemistry, 17 (Eds. Whistler, R.L. and Be Miller, J.N.), Academic Press, New York, 1962, 1-30.

13. Jackson ML. Soil chemical analysis, Ed: Prentice-Hall of India Pvt. Ltd., New Delhi, 1967, 498.

14. Lafindra D, Shewry PR. Improving cereal grain carbohydrates for diet and health. J Cereal Sc. 2014; 59(3):312-316.

15. Marisco G, Miscera E, Dimatto S, Minuti F, Vicenti A, Zarrilli A. Evaluation of animal welfare and milk production of goat fed on diet containing hydroponically germinating grains. Italian J Animal Sci. 2009; 8(2):625627.

16. Morgan J, Hunter RR, O'haire R. Limiting factors in hydroponic barley grass production. In: $8^{\text {th }}$ Inter. Cong. soilless culture, Hunter's Rest, South Africa, 1992.

17. Mutum lamnganbi, Surve US. Biomass yield and water productivity of different hydroponic fodder crops. J Pharmacognosy Phytochemi. 2017; 6(5):1297-1300.
18. Naik PK, Singh NP. Hydroponics fodder production: an alternative technology for sustainable livestock production against impeding climate change. Model Training Course on Management Strategies for Sustainable Livestock Production against Impending Climate Change. Southern Regional Station, National Dairy Research Institute, Adugodi, Bengaluru, India, 2013, 70-75.

19. Naik PK. Hydroponics technology for fodder production. ICAR News. 2012; 18(3):4.

20. Naik PK, Dhawaskar BD, Fatarpekar DD, Chakurkar EB, Swain BK. Nutrient changes with the growth of hydroponics cowpea (Vigna unguiculata) sprouts. Indian J Animal nutr. 2016; 33:357-359.

21. Naik PK, Dhuri RB, Singh NP. Technology for production and feeding of hydroponics green fodder. Extension Folder No. 45, ICAR Research Complex for Goa, Goa, 2011.

22. Naik PK, Swain BK, Chakurkar EB, Singh NP. Effect of seed rate and proximate constituents of different parts of hydroponic maize fodder. Indian J Animal Sci. 2017; 87(1):109-112.

23. Ravindran G. Studies on millets proximate composition, and phytate and oxalate contents. Food Chem. 1991; 39:99-107.

24. Sneath R, Mc Intosh F. Review of hydroponic fodder production for beef, cattle. Queensland Government, Department of Primary Industries, Dalby, Queensland, 2003.

25. Mayer AM, Poljakoff-mayber A. The germination of seeds, Pergamon Press, Oxford, UK. Mobilization. D. R. Murray. New South Wales, Australia, Academic Press Australia. 1974; 2:77-115. 